\title{
PARTY WALL AGREEMENTS AS REAL COVENANTS
}

A MID a field of law of peculiar interest to the student beof covenants running with the land - the subject of party wall covenants seems especially attractive. Here we have a form of covenant which has appealed to most courts as a sensible and desirable arrangement for the use and development of realty. Yet current legal theory is against the validity of such an agreement as a running covenant, passing with the conveyance of the land. ' As might be expected, the courts tend to follow their natural instincts, such covenants are being more and more generally upheld, and legal theory is left to stew in the difficulties of its own concocting. ${ }^{2}$ It is proposed herein to reëxamine the problem, with a view of testing the soundness of such legal theory and of determining whether current judicial practice does violate the policy of applicable and analogous legal rules. The cases on the subject were carefully collected and analyzed some years ago by Profeśsor Ralph W. Aigler in a learned and excellent article ${ }^{3}$ and hence we need not repeat that task but may confine ourselves to a consideration of the principles thought to underlie the problem.

To understand the difficulties of legal theory herein involved, we ought first to remember the generally recognized essentials of a real or running covenant. In order that a covenant may "run with the land," to use the well-known metaphorical expression signifying the transfer of the covenant rights or duties with the transfer of the land to which the covenant relates, there must be (I) observance of the formalities requisite to the making of a technical covenant or promise under seal; (2) an intention

1 See 2 Tiffany, Real Property, 2 ed., I262, I263. See Ralph W. Aigler, "The Running with the Land of Agreements to Pay for a Portion of the Cost of Party-Walls," to MrcH. L. Rev. I87. And see 8 CoL. L. Rev. I2I (arguing that all such covenants must be held personal); 4 Cor. L. REv. 44I ; I CoL. L. REv. 257 .

2 Cases are cited in the notes following and also in the authorities given in note I. For interesting remarks as to the divergence of theory from common sense in this connection, see McCormick v. Stoneheart, I95 S. W. 883 (Tex., I917).

3 See note I, supra. 
of the parties that the covenant should so run; (3) a promise of such kind that it may be held "to touch or concern the land; " and (4) "privity of estate." *

The first two requirements need not here be discussed, since their general nature is probably apparent. ${ }^{5}$ The third is designed to establish some degree of connection between the covenant and certain realty, and it necessitates, as a scientific method of test, the measuring of the legal relations of the parties with and without the covenant. If the promisor's legal relations, in connection with the land in question, and not merely as' an individual, are lessened or materially modified, the burden "touches or concerns" the land; if the promisee's legal relations of like kind are increased or materially modified, the benefit "touches or concerns" the land. The suggested test was first developed by Professor $\mathrm{H}$. A. Bigelow in a valuable article, to which the reader is referred for a complete discussion of the complex problem caused by the application of this requirement. ${ }^{6}$ Perhaps two examples may serve, however, to indicate the method. An agreement by a lessee to leave part of the leased land unploughed each year satisfies the test as to both benefit and burden, for it lessens the privileges of user which would otherwise have been the lessee's by virtue of his lease, while it gives a right which benefits the lessor in his reversion in the land by securing a crop rotation. ${ }^{7}$ But a covenant by the lessee to pay taxes for the lessor on other than the leased land imposes a duty upon the lessee unconnected with the leased premises, and grants a right to the lessor which is not for his benefit as reversioner, and hence the test is not satisfied. ${ }^{8}$

4 See Charles E. Clark, "The Doctrine of Privity of Estate in Connection with Real Covenants," 32 YALE L. J. I23.

5 As to how far mere acceptance of a deed poll may be treated as a covenant see 2 TIFrany, op. cit., I402; SIMs, Covenants other than Covenants For TITLE, I88-I95. That the use of the word "assigns" is not an absolute essential in order that a covenant may run, see authorities given in the writer's article previously cited, 32 YALE L. J. I23, I24, nn. 7, 8.

6 See Harry A. Bigelow, "The Content of Covenants in Leases," I2 Micr.

L. Rev. 639, 30 LAw Q. Rev. 3r9. See also note by Aigler, I7 Mich. L. Rev. 93.

7 Cockson v. Cock, Cro. Jac. I25 (I606); Chapman v. Smith, [I907] 2 Ch. 97. See 7 Cos. L. Rev. 627.

8 Gower $v$. Postmaster-General, 57 L. T. R. (N. S.) 527 (I887). See Charles E. Clark, supra, I25, I26. See also note 13 , infra. 
The requirement of privity of estate has caused much difficulty. The writer has recently had occasion to consider the problem in detail and hence will state here only the conclusions he has previously reached. ${ }^{9}$ This essential has been variously viewed as stating three quite dissimilar requirements: (a) succession to the estate in the land of one of the parties to the covenant; (b) succession of estate also between the parties to the covenant at the time of its making; and (c) the doctrine originating in Massachusetts, sometimes termed the Massachusetts doctrine of "substituted privity"-mutual and simultaneous interests of both parties to the covenant in the land, outside of the covenant and at the time of its making. If $\mathrm{C}$ wishes to enforce against $\mathrm{D}$ a covenant made to $\mathrm{A}$, his predecessor in 'the ownership of Blackacre, by B, D's predecessor in the ownership of Whiteacre, there is sufficient privity of estate under (a) by the mere succession of interest of $\mathrm{C}$ to $\mathrm{A}$ and $\mathrm{B}$ to $\mathrm{D}$; but under (b) there must also have been a conveyance of a realty interest between $A$ and $B$ at the time the covenant was made; and under (c) A and B at the same time must each have had a recognizable legal interest in either one of the two pieces of land. Theory (b) has no justification in either history or principle and adds a purely arbitrary requirement. Theory (c) likewise has no historical justification, and while it may find some little favor as expressing a policy opposed to incumbrances on land, it would seem on the whole undesirable. The four requirements above stated should be sufficient, without the addition of other arbitrary requirements. This leaves merely (a) as a complete statement of requirement number 4 , with compliance secured by the mere conveyance of the land, this being the principle justified both by history and by policy. ${ }^{10}$

9 See Charles E. Clark, supra. See also 2 I MICH. L. Rev. 593.

10 Before the statement made by Lord Kenyon in Webb $v$. Russell, 3 T. R. 393 ( 1789 ), without the citation of any authority, that privity of estate is necessary between covenantor and covenantee, there seem to be no precedents for such a requirement. In fact many old cases are contrary and commentators have had great difficulty in their attempts to explain them away. E.g., Mr. Justice Holmes' explanation of Pakenham's Case, Y. B. 42 Edw. TII, 3, pl. I4 (I368). See Holares, The Comaron LAw, 37I et seq. The traditional explanation is that real covenants have been developed from warranties, and that a conveyance was necessary in the case of the ancient implied warranty (which was abolished as to a conveyance in fee by Quia Emptores in I290). But the need 
The statement of this requirement in this form really answers two further questions of some importance in our present problem. Must there be both a dominant and a servient tenement in order that a covenant may run? And may the benefit and the burden of a covenant run separately? Under the Massachusetts doctrine of privity there must be, in practically every case, a relation of dominancy and serviency. Blackacre must be held bound to Whiteacre. ${ }^{11}$ But such a requirement seems unjustified, and usually a covenant may run where only one party to it owns the land involved. This indicates the answer to our other question, for this means that the benefit may run when the burden is in gross, as in the case of the ordinary warranty, and that the burden may run when the benefit is in gross, as in the case of an obligation to pay a named person for the use of property..$^{12}$ If either burden or benefit may thus run

of the conveyance in the case of the implied warranty was to furnish the basis for the implication of a warranty, and where the warranty is express there is no occasion for requiring a conveyance. See Charles E. Clark, supra, 32 Y L. J. I23, I37 et seq. Again, the covenant seems more analogous to the old fine than to the ancient implied warranty. Many such fines which run with the land are enforced in the action de fine facto which seems hardly distinguishable from the action of covenant. The latter action, by 1482 , lay to enforce a fine. Bingham v. Merton, Y. B. 22 Edw. IV, I, pl. 6 (I482). See such cases collected in 32 YaLE L. J. I23, I40, n. 80. On principle such an arbitrary requirement has little to commend it. The Massachusetts theory seems to require a preëxisting incumbrance on the land such as an easement. But generally such easement is found where the promised acts by the owner of Whiteacre are done for the benefit of Blackacre, and it is only where one end of the covenant is in gross that the Massachusetts doctrine becomes effective to strike down the covenant. Where one end is in gross and hence personal, the life of the covenant is necessarily limited, and the incumbrance on title small. The desirability of enforcing some covenants of that kind (see note I2, infra) would seem to outweigh the limited advantages of the Massachusetts rule in avoiding the running of a few covenants. See 32 Y YLE L. J. I23, 145 .

$11 \mathrm{~A}$ possible exception is apparently a covenant in aid of an assignable profit or easement in gross. Query, if the Massachusetts courts would hold such a profit or easement sufficient to supply the required privity?

12 See 32 YALE L. J. I23, I26-I3I. Cases where the burden only is in gross are not unusual. See Nat'l Union Bank at Dover $v$. Segur, 39 N. J. L. I73 (I877) (covenant not to compete). Also there is the ordinary covenant of warranty in a deed, which under the Massachusetts rule must be regarded as a special exception. Cases where the benefit only is in gross are more rare. A leading case is a party wall case hereinafter considered. Conduitt $v$. Ross, ro2 Ind. I66, 26 N. E. Ig8 (I885). See also Gibson v. Holden, Ir5 Ill. I99, 3 N. E. 282 (1885). Holmes, J., is contra in Lincoln v. Burrage, I77 Mass. 378,59 N. E. 
separately when the other is in gross, it should follow that either should run separately when the other is appurtenant to an estate in land. This problem is not often discussed, and there is some authority that both must run or neither can run; but the better view, it is submitted, is to the contrary. Hence we must test each end of the covenant separately, to ascertain both if the parties intended it to run and if it may legally be permitted to do so. ${ }^{13}$

Turning now to party wall covenants, we perhaps should pause to notice the nature of the property interests in such walls. It has been attempted to restrict the term party wall to a division or boundary wall between adjoining land owners who each, therefore, have an interest in the wall. ${ }^{14}$ The normal situation will be where the wall is erected on the boundary line, and here by the English rule the parties will be held to own the wall in common; but in this country they will ordinarily be held to own, each in severalty, that portion of the wall on his

67 (IgOI), hereinafter criticised ("it would be most unusual to have the rights in gross and the duties appurtenant"), and in Walsh v. Packard, I65 Mass. I89, 42 N. E. 577 (I896). These cases but carry out, however, the Massachusetts view of privity. See note Io, supra. See also, contra, 2 CoL. L. Rev. 554 . Consol. Arizona Smelting Co. v. Hinchman, 212 Fed. 813 (Ist Circ., I9r4), is likewise contra, but not on this express ground. There a covenant by a purchaser of mining property to pay for it in part out of future net eamnings was held not to pass. It is a poorly reasoned case in which the dissenting judge and the lower court [I98 Fed. 907 (D. Me., I9I2)] seem clearly to have the better of it. Aldrich, J., dissenting, well characterizes some of the current doctrines of privity of estate when he speaks of the "apparent demonstration" by counsel "that if the question whether the covenant runs is contingent upon the existence of a reversionary right, the contingency is not founded upon reason and if applied to a situation like this, that the denial of a meritorious right would be based upon grounds of fiction rather than upon grounds of reason." See Henry U. Sims, "Notes on Codifying Real Property Law in the United States," 36 HARv. L. REv. 987, 99ז, n. 20: "an interesting example of the con-

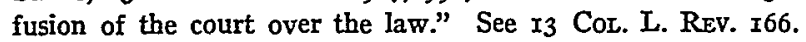

13 This is the basis of Professor Bigelow's criticism of Congleton v. Pattison, Io East, $x_{30}$ (I808), where the lessee agreed to employ in a leased silk mill only persons complying with specified requirements as to their legal settlements. Here the lessors were benefited only in respect to the poor rates and not as reversioners, and hence an assignee of the lessors should not be entitled to sue; but since the promisor was restricted in his use of the premises, the actual decision refusing to allow the lessors to sue the assignee of the lessee seems unsound. See H. A. Bigelow, supra, I2 Mich. L. REv. 639. See also 32 YaIs L. J. I23, I26-I 28.

14 See I Reeves, Reat Property, 285-289. 
side of the line with a cross-easement of support in his neighbor's portion. ${ }^{15}$ A wall entirely on the land of one party will normally be owned by that party, but of course he may, if he choose, grant his neighbor an interest therein, such interest usually taking the form of an easement. ${ }^{16}$ The parties often desire to vary or add to their mutual legal relations respecting the wall. Such a covenant, for example, might contemplate ownership of the wall by one party with the renting of an easement to the other. ${ }^{17}$ Or it might merely take the form of a provision for the mutual repair and upkeep of the wall. ${ }^{18}$ Such covenants are clearly sustainable as running covenants. ${ }^{19}$ But the case which causes difficulty, although it is of frequent occurrence, is the covenant by one party to pay in part for a wall to be built by the other, either on his own land or, more usually, on land of both, payment to be made not when the wall is built but only when it is used. We must, therefore, devote our attention to this situation.

$\mathrm{A}$ and $\mathrm{B}$ are adjoining landowners. A wishes to build on his lot and to build to the edge of his lot; B is not yet ready so to develop his lot. So they make a covenant whereby $A$ gets the privilege of immediately building a wall one half of which is to rest on B's premises, and B gets the privilege of building upon the wall or using it for support of his building whenever he or his assigns desire to do so, upon paying to A or A's assigns one half the cost of the wall. Such an arrangement is frequently resorted to and seems mutually satisfactory to the parties. B is compelled to pay his share of the cost of the wall only when he makes beneficial use of it, while A obtains the privilege of building with a possible chance of future partial reimbursement.

\footnotetext{
15 Ibid. And see 9 Cor. L. Rev. 74.

16 Cf. Knappenberger v. Fairchild, 2I0 Pa. St. I73, 59 Atl. 986 (I904) (privilege of inserting beams).

17 See Logan v. United Interests, Inc., 236 N. Y. I94, I40 N. E. 240 (I923), discussed infra.

18 Maupai v. Jackson, I39 App. Div. 524, I24 N. Y. Supp. 220 (I9IO), affirming 64 Misc. 407 , II8 N. Y. Supp. 5I3 (IgO9).

19 Whatever doctrine of privity of estate may be applied, it is held that the required privity exists, since there is both a conveyance of at least an easement and a covenant in aid of the easement. See Ralph W. Aigler, supra, to Micr. L. REv. I87. Query, however, where the wall is not yet built. See note 30 , infra.
} 
What attitude is the law to take towards such an apparently desirable and amicable arrangement?

The answer must depend, in the first instance, upon the intention of the parties. It may be that $B$ will agree to pay at once and $A$ to build at once. $B$ will then acquire his interest in the wall as soon as it is built, the covenant will be entirely personal, and there will be no difficulty as to it. Such course, however, is rather unusual unless $B$ contemplates immediate use of the wall. Next, it may be that the parties intend that whoever owns B's lot and builds on the wall shall owe the obligation but it shall always be owed to A personally. It is suggested that actually the parties will rarely so intend, but if they do, there ought to be no objection to the fulfillment of such intention. As hereinafter pointed out, such an obligation seems to comply with the rule that it must touch or concern the land, ${ }^{20}$ and the only objection is the one above noted as unsound, namely, that there is no dominant and servient tenement. Hence the leading case of Conduitt v. Ross ${ }^{21}$ seems clearly sound in upholding such an arrangement, if, as seems probable, the court has correctly interpreted the intention of the parties. ${ }^{22}$ If the discussion above of the objection here raised has been followed, it will probably not seem strange that Massachusetts holds to a contrary doctrine. In an endeavor to restrict the running of covenants to those not in gross, that court, through Mr. Justice Holmes in Lincoln v. Burrage, ${ }^{23}$ refused to uphold a perfectly reasonable and sensible contract of this character. There the builder of the wall owned both the lots on which the wall rested, and at his death his executors sold each piece with a covenant by each of the grantees and his assigns to pay such executors one half the cost of the wall upon using it. The decision, re-

${ }^{20}$ See discussion infra.

21 I02 Ind. I66, 26 N. E. Ig8 (I885). See note I2, supra.

22 The language of the original covenant seems to justify this interpretation. Moreover, the promisee in later assigning the land expressly reserved her interest in the covenant. There would seem to be no objection to giving effect to such attempted severance of the covenant from the estate in the land. The one owing the duty is the only one to object, but he is hardly harmed by the fixing of the right in a certain person. Cf. Fowler $v$. Koehler, 43 App. D. C. 349 (I9I5). The rule against severance applied to easements is due to the disfavor with which easements in gross are regarded. See 20 HaRv. L. REv. I36.

23 I77 Mass. 378,59 N. E. 67 (Igor). 
fusing to enforce such a contract against the assigns of a grantee on the ground that the right to performance was held in gross, seems wholly objectionable and shows the unfortunate results of attempting to enforce an arbitrary requirement of "privity of estate." 24

The more usual case would seem to be that in which both the duty to pay and the right to receive payment are intended to run with the lots of the non-builder and the builder respectively. In many of the cases this intention is expressed so clearly as to be beyond doubt. Further, it is submitted that wherever the contract does not show a contrary intention, the inherent probabilities are in favor of such a purpose. This is, therefore, the most important case, and it is also the one where legal justification of the intended result seems the most difficult.

There seem to have been two theories offered to sustain the running of such a covenant. According to the first, $B$, the nonbuilder, immediately becomes the owner of his normal interest in the wall (an interest in severalty in that part on his land with an easement in the remaining part) but he or his assigns are subject to a duty to pay $A$ or his assigns a sum of money usually a proportion of the cost or value of the wall - upon using it. The difficulty here is to discover how the right to receive a certain sum of money may be held to touch or concern the land. ${ }^{25}$ It has even been thought that the burden, the duty to pay, is also collateral on the ground that a duty to pay money has no connection with the land, since performance may be made by any one. ${ }^{26}$ This seems too narrow a conception. A duty to pay money in return for a privilege of user of realty directly concerns the land. It is a burden placed upon the normal privileges of user, a burden which would not exist except

24 The case is, however, approved by Professor Aigler. See Io MrCr. L. REv. 187. See also I Cor. L. Rev. 257; I4 HaRv. L. Rev. 296.

25 There seems to be no objection so far as privity of estate is concerned. See note I9, supra.

26 See 2 Cot. L. Rev. 554, criticising Jordan v. Indianapolis Water Co., I59 Ind. 337,64 N. E. 680 (I902), stating that rent is an exception and citing Graber v. Duncan, 79 Ind. 565 (I88I), as holding that a covenant to pay taxes does not run. This case was, however, one by a grantor of real estate to pay current and back taxes only, and was correct, though not an authority for the general proposition stated. $C f$, also the comments cited in note I, supra. 
for the covenant. Moreover, practically any affirmative obligation concerning land may be considered, in a certain sense, as only a burden to pay money, viewed from the promisor's standpoint, since he may hire an agent to perform for him. Carried to its logical conclusion, therefore, the argument that a duty to pay money is necessarily collateral would require the holding that affirmative covenants in general are collateral - a clearly untenable position. Hence it is held by the better-reasoned authorities that an obligation of this kind, of which a duty by a tenant to pay taxes may perhaps be a not unusual example, may run. ${ }^{27}$ As to the benefit, however, the privilege has, on the assumed theory, already passed; there is nothing further for the lot owner, as such, to do; and there remains only a collateral right to receive a sum of money, a right just as valuable to any one else as to the lot owner. It does not seem possible to bring such right within any of our ideas of "touching or concerning," and therefore our whole assumed theory is unable to bear the strain we wish to put upon it. ${ }^{28}$

The second theory assumes that, by the covenant, the builder acquires the privilege to build a wall which he or his assigns will own exclusively until the payment is made, and when payment is made, ownership of one half of the wall and the usual party wall easements will then pass to the payer. This avoids the difficulty of touching or concerning, for the only one who can relinquish the interests contemplated as then passing is, of course, the then owner of the builder's lot. This seems to be the theory usually resorted to by writers, and, so far as they rely on any theory, by the courts also. ${ }^{29} \mathrm{It}$, too, presents difficulties.

The first difficulty would seem to be that it assumes an en-

27 Post v. Kearney, 2 N. Y. 394 (I849) (covenant to pay assessments) ; Gower v. Postmaster-General, 57 L. T. (N. S.) 527 (1887); Mason v. Smith, I3I Mass. 5Io (I88I); Wills $v$. Summers, 45 Minn. 90,47 N. W. 463 (r89o). See also covenants to pay rent, as in Van Rensselaer $v$. Read, 26 N. Y. $55^{8}$ (1863). See 2 TrFany, op. cit., I473, 1474 .

28 See Ralph W. Aigler, supra, to MrCH. L. Rev. I87.

29 Cordill v. Israel, $130 \mathrm{La}$. 138,57 So. 778 (I9I2); McCormick v. Stoneheart, supra, note 2; Berry v. Godfrey, I98 Mass. 228, 84 N. E. 304 (Igo8). Cf. Southworth v. Perring, 7I Kan. 755, 8I Pac. 48I, 82 Pac. 785 (I905). See Ralph W. Aigler, supra, Io MICH. L. Rev. 187. 
tirely unreal intention of the parties. It can hardly be thought that they really contemplate such a future passing of title. Possibly, however, we might overlook this objection on the ground that their main intention was to make a valid running covenant, and that, if necessary to give effect to such intention, we may ascribe to them such ideas, on points about which they had had no very definite views, as seem required. The unreality of the contemplated situation is, however, a drawback.

A second difficulty might be thought to arise under the latter two versions of the requirement of privity of estate, but since these are thought to be unsound and since the courts have not generally felt hampered by them, we may pass this point. ${ }^{30}$ The difficulty that no future deed of conveyance is contemplated may perhaps be surmounted by saying that the covenant operates as a contract to convey, and a deed might properly be demanded if the parties really thought they needed it (which they apparently do not). The final difficulty is one which the courts have not discussed but which the text-writers ${ }^{31}$ have thought insurmountable, namely, the Rule against Perpetuities.

It seems now well settled that the Rule applies to option contracts for the conveyance of an interest in land in the indefinite future. $^{32}$ Here there is an agreement giving the non-builder the option of acquiring a substantial interest in realty in the remote future. It seems difficult to distinguish this case from other option contracts held invalid under the rule. Hence this theory also will not, apparently, stand the strain attempted to be put upon it.

It is thought that this theory should be rejected, but an argument that the interest here created is not within the spirit, though perhaps within the letter of the Rule, may be made. We may

30 The reason usually given is that stated in note I9, supra, namely, the passing of an easement, but since the easement is assumed not to pass and not to exist until long after the making of the covenant, it is difficult to see how on theories (b) and (c) above noted there is privity.

${ }^{31}$ See note I, supra.

32 London \& S. W. Ry. Co. v. Gomm, 20 Ch. Div. 562 (I882); Lewis Oyster Co. v. West, 93 Conn. 518, I07 Atl. I38 (I9I9) with comment in 29 Yale L. J. 87. See Gray, Rule against Perpetuities, 3 ed., § 330. See Joseph Warren, "The Progress of the Law - Estates and Future Interests," 34 Harv. L. Rev. 639, 642. Cf. I4 MICH. L. Rev. 23I. 
start with an interesting suggestion made by Mr. Edwin $\mathrm{H}$. Abbot, Jr., ${ }^{33}$ and repeated by Professor G. E. Woodbine. ${ }^{34} \mathrm{Mr}$. Abbot admits that options in gross are within the spirit of the Rule, but argues that options appurtenant to other interests such as leaseholds, are not, since they, unlike the former class of options, encourage and do not discourage improvements upon the land. Professor Woodbine repeats this argument, and applies it to the positive option where the power is at all times in the option holder, as distinguished from the negative option of preëmption, which simply gives the option holder the first chance if the grantor decides to transfer. It is pointed out that neither the option appurtenant nor the positive option suspends the power of alienation of the interest, and it is argued that they well might be considered as vested interests. It is admitted, however, that the authorities seem to be contra. ${ }^{35}$

A third theory has suggested itself to the writer, which, it is submitted, meets the objections urged against the other theories. It is in effect that the non-builder's title in the wall should not be considered as one absolute interest which can only be acquired at a single instant of time, but that realistically considered it is an aggregate of legal relations ${ }^{36}$ of which certain ones may pass at one and others at another time. It would seem that the parties by their agreement contemplate that the non-builder shall acquire his general interest in the party wall - severalty title in part plus easements - immediately on the execution of the contract, if the wall is already built, otherwise immediately when it is built, but that he is restricted from the exercise of an important privilege of enjoyment and user, namely, the building on the wall and the using of it for support. This, it is thought, is an interpretation which would appeal to the parties themselves as sensible, whereas the others would not. Would not the non-builder be surprised to be told that he has no ownership in the wall until he pays the money? Would he

33 "Leases and the Rule against Perpetuities," 27 YaLE L. J. 878.

34 See 29 YaLE L. J. 87.

35 Ibid. See also Edwin H. Abbot, Jr., "Covenants in a Lease Which Run with the Land," 3I YAIE L. J. I27, I35, I36.

${ }^{36}$ For discussion of title in this view, see Walter W. Cook, "Hohfeld's Contribution to the Science of Law," 28 YaIE L. J. 72I, 729, reprinted in HoHFeid, Fundantental Legar Conceptions, 3, I2. 
not be startled to learn that he, is not entitled to an injunction restraining the builder from tearing down the wall? In fact would he not probably succeed in getting the injunction if he should ask for it? ${ }^{37}$ It would seem a fairer interpretation to say that both builder and non-builder own the wall as in normal fashion, but that there is a restrictive agreement against a certain kind of use by the non-builder or his assigns until he or his assigns shall make the required payment. The non-builder may have such enjoyment of the wall - enclosure of his lot, shade, and the like - as does not violate the restriction. The situation is analogous to that of the restrictive agreement enforceable in equity, sometimes termed an "equitable easement" or an "equitable servitude." 38 Such servitude in this case may be terminated at any time by the payment to the builder or his assigns of the stipulated amount.

This theory of the situation would avoid any difficulty of " touching or concerning," for both sides of the agreement would fill all requirements. As to the non-builder's part, the conclusions previously stated concerning the money obligation apply, and apply with all the more force since coupled with the burden of payment is the privilege of user, a privilege of no value except to the lot owner. As to the builder's part, upon receipt of the agreed payment he loses a right that only he (or his assigns) shall use the wall. Since such right has obviously been of special importance to him only in his capacity as lot owner, the payment to him in return for the loss of the right touches or concerns the land, under the test above stated. ${ }^{39}$

Is the Rule against Perpetuities violated? The answer upon all the analogies which have occurred to the writer seems clearly in the negative. The first analogy might be the well-settled rule that a vested interest never offends the Rule even though possession cannot be taken until a period beyond that permitted by the Rule. ${ }^{40}$ The Rule, therefore, apparently does not apply to

37 Cf. Knappenberger v. Fairchild, supra, note $x 6$.

38 See Roscoe Pound, "The Progress of the Law, rgr8-rgr9-Equity," 33 HaRv. L. REv. 8I3.

39 See note 6, supra.

40 Dodge v. Bennett, 2I5 Mass. 545, I02 N. E. 9I6 (I913); Salisbury v. Salisbury, 92 Kan. 644, I4I Pac. I73 (IgI4). See Gray, RuLE AganNst PeRPETUTTIES, 3 ed., \$ 205 . 
every legal relation in land, but only to those which rise to the dignity of a recognized "interest," or "estate," or "title." Restrictions on possession or user are too limited in extent to come within it. Here we have a vested interest in the wall in the non-builder, and only postponement of a certain degree of possession.

Again, the restrictions here seem to come within the category of restraints on enjoyment only, which are like restraints on alienation and unlike perpetuities, and hence, as Professor Gray so strenuously argued, do not come within the objections against remoteness. Professor Gray, in dealing with the rule of Clafin v. Clafiin, ${ }^{41}$ which allowed the continuance of a trust for the sole absolute interest of a beneficiary beyond his minority, states that the beneficiary's interest may be considered vested, but that another question then arises with which the Rule against Perpetuities has nothing to do, viz.: Can the possession of a vested interest be postponed?

$\mathrm{He}$ answers this question by saying that the Rule against Perpetuities does not prevent such postponement, that it merely settles the time within which interests must vest, and that when once vested, they are all, present and future alike, subject to the same restraints against alienation, with which the Rule has nothing to do. And he asserts that the theory that the Rule applies is " one more instance of the confusion wrought by confounding the Rule against Perpetuities with the rules against restraints on alienation." ${ }^{42}$ Professor Kales' views on this point are in accord. ${ }^{43}$

It would then follow that the Rule against Perpetuities does not apply and that the only objection which can be raised is that the restriction is unreasonable. If objection on this latter ground is sustained, it would mean not that no interest passed to the non-builder, but that the entire interest passed at once and only the restriction is invalid. Consideration of this objection may be postponed until we have examined the final, and, as it seems, the most appropriate analogy to our case in connection with the Rule against Perpetuities, namely, the termination of an equitable restriction or servitude.

41 I49 Mass. Ig, 20 N. E. 454 (1889).

42 GraY, op. cit., § I2If.

43 KALES, FUTURE INTERESTS, 2 ed., $\$ 658$. 
It appears that the termination of an easement is not subject to the Rule against Perpetuities. The law has always frowned upon easements as incumbrances, and has permitted them to be terminated by oral license acted upon or by abandonment by the owner, even though perhaps the formalities of a deed might seem called for. ${ }^{44}$ So the equitable servitude may be lost in several ways, such as by laches in asking court aid, by violations by the owner thereof, or by changes in the condition of the neighborhood. In fact every such servitude is treated as though granted upon an implied limitation to last only so long as the neighborhood remains substantially unchanged. ${ }^{45}$ The law favors a return to the normal. Professor Gray says:

"As the Rule against Perpetuities affects the beginning only of future interests, and does not concern itself with conditions subsequent, except so far as they are also conditions precedent, a provision that an easement or other jus in alieno solo shall terminate on a certain contingency is not invalidated by the remoteness of the contingency." 46

Here we have essentially an equitable servitude in favor of the builder, which is subject to termination whenever the nonbuilder chooses to pay the agreed amount. It seems clear that the termination of the builder's restriction is one of the class of transfers most favored in law and that it does not offend the Rule against Perpetuities. And it is submitted, therefore, that we may safely conclude that all objection based upon the Rule is avoided upon the analysis here suggested. ${ }^{47}$

To turn now to the objection that the restriction must be reasonable, we may note that the rule of policy seems especially directed to the restraint on alienation, the clog on the power of transfer of property interests. ${ }^{48}$ Only a comparatively few

44 For a brilliant though futile protest against the doctrine of abandonment of easements, see II Cor. L. REv. 777.

45 See 34 HaRv. L. Rev. 786; 3x HaRv. L. Rev. 876.

46 GRAY, op. cit., § 279, citing Switzer v. Rochford [Ig06] I Ir. R. 399. See also Hall v. Turner, rro N. C. 292, I4 S. E. 79I (1892).

47 See also GRAY, op. cit., $\$ 330 \mathrm{a}$, to the effect that even though the right to specific performance of a contract may not exist because of the rule, yet a legal action on the contract still remains.

48 Thus Gray's researches dealt almost wholly with that phase of the question. See Gray, Restratnis on the Alienation of Property, 2 ed. 
cases seem to turn directly upon the reasonableness of a restriction on the privilege of enjoyment, such as we have here, which can hamper alienation in only a minor degree, if at all. Nevertheless, both the authorities and a justifiable policy seem to require that such a restriction must be reasonable in order to be valid. ${ }^{49}$ As applied to the cases of equitable servitudes, there is apparently no further statement of the rule than the broad one that the restriction shall be reasonable and not offend public policy. ${ }^{50}$ From the analogies of the more or less drastic equitable servitudes which are currently upheld either for a period or indefinitely, subject to the implied limitation of change of neighborhood, we may safely conclude that the restriction here under consideration is not in danger of being considered unreasonable. $^{51}$ A restriction that one shall not make a certain beneficial use of an improvement on realty until one has paid one's fair proportion of the cost or value of it would surely appeal to a court as eminently fair and reasonable.

Here we may consider the special rule advocated by Professor Kales as a measure of the reasonableness of the restraint on alienation disclosed in the Claftin case. As the reader will recall, Professor Gray argued that the interposition of a trust when the beneficiary's interest was absolute was to be considered both on policy and authority as an illegal restraint on alienation. ${ }^{52}$ Professor Kales denied this but did meet Gray's position to the

49 Pavkovich v. Southern Pac. R. Co., I50 Cal. 39, 87 Pac. I097 (Igo6); Rubland v. King, I54 Wis. 545, I43 N. W. 68I (I913). See A. W. Scott," Control of Property by the Dead," 65 U. oF PA. L. REv. 632, 646.

50 See Highland Realty Co. v. Groves, I30 Ky. 374, 377, II3 S. W. 420, 421 (Ig08). Such restrictions are upheld "when not repugnant to some plain provision of the law, and . . . not unreasonable in themselves."

51 For examples, see notes 49 and 50, supra, and see especially cases such as Gray v. Blanchard, 8 Pick. (Mass.) 283 (1829), upholding a condition that no window shall be placed in the north wall of a house for thirty years; and Tobey v. Moore, I30 Mass. 448 (I88I), upholding perpetual restrictions that no building conveyed to be used for certain trades should ever be erected upon certain land, or within a certain distance of the street. See Am. Unitarian Ass'n v. Minot, I85 Mass. 589, 595, 7 I N. E. 55I, 553 (I904): "The duration of an equitable restriction is a question of the intention of the parties to be determined by construing the words used in the light of attending circumstances."

52 Gray, Restratnis on Almenation, 2 ed., \$§ r24l-124p; Gray, Rule AGAINST PERPetUItIES, 3 ed., §§ I2IC-I2 Iii. 
extent of agreeing that a perpetual trust of this character was undesirable. He therefore suggested that the interposition of a trust to last longer than a period equal to that adopted for the application of the Rule against Perpetuities should be considered an unreasonable restraint, and hence that the beneficiary might secure termination of the trust at any time. ${ }^{53} \mathrm{He}$ found authority for this view in English cases which had confused the distinction urged by Professor Gray between objections based on remoteness and objections based upon restraint of alienation. ${ }^{54}$ This view has received the approval of textwriters, ${ }^{55}$ and it seems desirable in the particular case to which Professor Kales argued that it should be applied. Professor Gray himself, although he continued to argue against the rule of the Clafin case, agreed that if it were to be adopted at all, it should be restricted in some such manner as that suggested by Professor Kales. ${ }^{58}$ There is, however, no authority for applying the rule to the ordinary equitable servitude which seems to meet with general popular favor. Such a servitude fosters improvements, and the more extended use and development of realty. On the other hand, the interposition of a naked trust between the beneficial owner and the subject-matter of his property interest is the creation of an encumbrance of no conceivable advantage to such owner or anyone connected with him. It does not even protect him from himself, for he may sell his interest if he can find a purchaser to accept it so encumbered..$^{57}$ The only argument urged for it is that it carries out the wishes of a person now dead-the former owner of the property - who was presumably poorly advised, in view of the useless character of the restriction. There is a strong argument of policy in limiting such a restriction, even if we are unwilling to take the view of Professor Gray and of the English

53 KaIES, Future INTERESTS, 2 ed., $\$ \S 658,659,737$. See also the following discussions by the same author: "Vested Gifts to a Class and the Rule against Perpetuities," Ig Harv. L. Rev. 598; "Several Problems of Gray's Rule against Perpetuities, Second Edition," 20 HaRv. L. REv. I92; 4 IrL. L. Rev. 28x.

54 Cf. ibid. and In re Ridley, II Ch. Div. 645 (1879).

55 See Joseph Warren, "The Progress of the Law-Estates and Future Interests," 34 HARv. L. REv. 639, 647, and authorities cited.

56 Gray, Rute agatnst Perpetuities, 3 ed., § r2ri.

57 De Ladson v. Crawford, 93 Conn. 402. 106 Atl. 326 (I9I9). 
cases that it is improper in any event. Policy and authority, however, neither require nor justify such treatment of the equitable servitude. ${ }^{58}$ It is therefore believed that the party wall restriction under consideration may safely pass all tests of reasonableness.

As pointed out above, the modern cases sustain the running of such covenants, ${ }^{59}$ and the conclusion of our argument is that such holding not only is desirable from the standpoint of policy, but is perfectly consistent with sound legal theory. Some states have achieved the same result by statutes. ${ }^{60}$ In a few jurisdictions the situation still remains anomalous. The situation in New York is sufficiently interesting to deserve special mention.

Since the New York statute against perpetuities is directed only against the suspension of the power of alienation, ${ }^{61}$ it might be thought that little objection would be found to these covenants. Moreover, a liberal view of privity of estate was early taken in New York. ${ }^{62}$ But, unfortunately, the court later became confused on the matter of privity of estate, ${ }^{63}$ and ruled in an unfortunately too well-known case, Cole v. Hughes, ${ }^{64}$ that a party wall covenant must be considered as only personal. Such a harsh and unnecessary ruling was bound to be limited, and in a later case, Mott v. Oppenheimer, ${ }^{65}$ a party wall covenant was

58 Possibly it may be desirable to limit the duration of all equitable restrictions to a stated number of years, as is done by the Massachusetts statute referred to in Loud $v$. Pendergast, 206 Mass. I22, 92 N. E. 40 (I9IO), but that, it is submitted, is a question for the legislature.

50 This is admitted by the authorities cited in note $\mathrm{I}$, supra. In addition to the cases cited by Aigler, supra, and among the more recent cases are those in note 29, supra, and Leek v. Meeks, I99 Ala. 89, 74 So. 3I (IgI6); Hill v. City of Huron, 33 S. D. 324 , 145 N. W. 570 (I914), 39 S. D. 530, I65 N. W. 534 (I9I7); Ellensburg Lodge No. 20, I.O.O.F. v. Collins, 68 Wash. 94, I22 Pac. 602 (IgI2); Horne v. Macon Tel. Pub. Co., I42 Ga. 489, 83 S. E. 204 (I9I4); Walker v. Gish, 273 Fed. 366 (App. D. C., I92I). Cf. Hanson v. Beaulieu, I45 Minn. II9, I76 N. W. I78 (I920).

Bo Younker v. McCutcheon, I77 Ia. 634, I59 N. W. 44I (I9I6). See Nathan Isaacs, "Statutory Party Walls," 7I U. OF PA. L. REv. 229. As to the District of Cólumbia regulations, see Fowler v. Koehler, 43 App. D. C. 349 (I915).

61 See Gray, Rute agatnst Perpetutries, 3 ed., \$ 748.

62 Van Rensselaer v. Hays, I9 N. Y. 68, 9I (I859).

63 See 32 Y YLE L. J. I23, I37, note 66; ibid., I4I, note 82.

${ }^{64} 54$ N. Y. 444 (I873). See a good statement of the unfortunate effect of this case on the law generally in McCormick $v$. Stoneheart, supra, note 2.

65 I35 N. Y. 312, 3I N. E. 1097 (1892). 
allowed to run. Other comparatively recent cases, refusing to allow somewhat similar covenants to run, have called for the making of careful distinctions between the cases. ${ }^{66}$ It seems now to be considered the law that, if the parties contemplate the immediate building of the wall and so state, the covenant will run, but if the parties are providing for the building of the wall, whenever it may be built, it does not. This seems to be simply a rule of thumb to decide what the parties' intention may be. It is unfortunate that it makes no attempt to ascertain or carry out the actual intent of the parties. But if they will only take pains to state that they contemplate that the wall shall be built at once, their agreement then can be carried out. ${ }^{67}$

More recently still it has been laid down as the rule that the burden of no covenant will be allowed to run with a fee in New York, but among the rather numerous exceptions stated to this rule is the case of party wall covenants. ${ }^{68}$ The confusion still remaining in that state is well illustrated by a case decided last June, Logan v. United Interests, Inc. ${ }^{69}$

That case turned upon a covenant made in 1883 by $A$, the owners of No. 6 Greene Street, New York, as parties of the first part, B, who held title to No. 8 Greene Street as trustees for $L$, parties of the second part, and $L$, the beneficiary, as party of the third part. A, in putting up a new building, had rebuilt and extended an old party wall, all of the extension being made on A's own land at A's expense. The covenant was in the form of a lease of this extension and provided that $A$ "do let and lease" to B, "their successors and assigns, the said wall" "as and for the party wall" between the two buildings, so long as Number 8 should stand and require the use of the same, "for the annual rent or sum of $\$ 326$ to be paid to them, the said parties of the first part, their heirs, executors, administrators or assigns" in semi-annual payments, "which rent the party of the third part for himself, his heirs and devisees of the said No. 8 Greene Street, hereby covenants and

66 Crawford v. Krollpfeiffer, I95 N. Y. I85, 88 N. E. 29 (I909); Sebald v. Mulholland, I55 N. Y. 455 , 50 N. E. 260 (I898).

67 See Ralph W. Aigler, supra, ro Micti. L. Rev. r87. Cf. 69 CENT. L. J. 44.

68 Miller v. Clary, 210 N. Y. I27, I03 N. E. III4 (I913).

${ }^{69} 236$ N. Y. I94, I40 N. E. 240 (Ig23) per Judge Cardozo. 
agrees shall be paid at all times and in the way above specified and does hereby irrevocably authorize and empower the parties of the second part and their successors to pay the same" out of income for his benefit, he further convenanting that "the payment of the aforesaid rent" shall be deemed an application of the amount thereof for his benefit under the terms of the trust, to which the trustees consented and agreed. The agreement further provided that A "for themselves, their heirs, executors, administrators and assigns" should keep the wall in order and repair at their sole cost, and contained provisions for the termination of the lease upon destruction of both buildings, and also upon the destruction of No. 8 unless the owners thereof should desire otherwise; and also that upon the destruction of No. 6, the owners of either lot might have a "right to terminate" on three months' notice. ${ }^{70}$ The owners of No. 8 then built upon the wall.' By mesne conveyances title to No. 6 came to the plaintiff. The interest of No. 8 was transferred by deed given by the beneficiary of the trust and (apparently) by the legal title-owners and in r920 came to the defendants, since which time no rent has been paid. In a suit for an installment of the rent the municipal court gave judgment for the plaintiff which was affirmed by the Appellate Term. The Appellate Division, however, held that the agreement was a party wall covenant and that, as such, it could not run. ${ }^{71}$ This is clearly not in accord with the present New York rule, and was repudiated by the Court of Appeals, but the latter court ruled that the defendants were not liable on the ground that originally only the beneficiary $\mathrm{L}$ was liable, and the defendants were not in privity with him.

It is submitted that the decision is erroneous and that on two different theories the defendants were liable: (I) as holders of the land and successors to the trustees they were liable for the rent; (2) as successors to the beneficiary they were liable on the covenant to see that the rent was paid. On the first ground, the court surely must be in error in saying that the trustees were not liable for the rent. A perpetual rent is valid

70 Facts above stated not appearing in the opinion have been verified from the record.

${ }^{71} 203$ App. Div. 634, I97 N. Y. Supp. Io9 (I922). 
in New York, ${ }^{72}$ and no technical words in a deed are necessary to create a rent so long as the intention is clear. ${ }^{73}$ This the court admits, and it cites authorities to illustrate the point ${ }^{74}$ but states that the context shows that "the obligation of payment is assumed, not by the lessee, the fiduciary, the holder of the title, but by someone else, the beneficiary." But with all due respect, this is just what is not done. The beneficiary covenants only that the rent shall be paid, and authorizes the trustees to pay the same out of the income from the trust. They and not he are to pay the rent. The wall is let to them for a stated annual rent to be paid to the lessors. The trustees were liable for the rent and the defendants as successors thereto in the ownership of the land should now be liable therefor. ${ }^{75}$

It is true that at common law a rent technically could not issue out of an incorporeal interest such as an easement. ${ }^{76}$ That rule was closely connected with the limitations put upon the remedy of distress and perhaps is no longer law. ${ }^{77}$ But even if it is, the liability of the trustees and consequently of the defendants is not altered. By leasing the wall the parties probably contemplated the transfer of a greater interest than an easement; but if only an easement passed, the debt in return therefor was analogous to rent and would be upheld upon similar principles. ${ }^{78}$ The question here is not whether distress will lie but whether the trustees assumed the obligation.

As to the other point, the defendants were in the direct line of conveyance from the beneficiary and no reason appears why they should not be bound by his covenant. The basis of the

72 Van Rensselaer v. Hays, supra, note 62; Van Rensselaer v. Read, supra, note 27 . See authorities collected in 28 C. J. 839 .

73 Attoe v. Hemmings, 2 Bulst. 28I; Doe v. Kneller, 4 Car. \& P. 3 (1829). See GILBERT, ReNTs, 30, 38; 2 TIfFanY, op. cit., I469.

74 One of the authorities cited seems especially analogous. Bower v. Hodges, I3 C. B. 765,774 (1853): "rent to be paid."

76 Cowton v. Wickersham, 54 Pa. St. 302 (I867). See 2 TIFrany, op. cit., $\S 4$ I4. See also 28 C. J. 860.

76 Williams v. Hayward, I El. \& El. IO40 (I859). See GrlbERT, RENTS, 20-28. 772 TIFFANY, op. cit., \$ 405.

78 See ibid. See Jordan v. Indianapolis Water Co., 159 Ind. 337, 64 N. E. 680 (I902); Raby v. Reeves, II2 N. C. 688, I6 S. E. 760 (1893). See 2 Cor. L. REv. 554. 
decision would seem to be that they cannot succeed to him since he did not have the legal title. In order to find an equally technical holding it would seem necessary to go back to $W e b b$ v. Russell, ${ }^{79}$ where it was held that a covenant made by a mortgagor was made by a stranger to the land. Surely an equitable title owner should not now be considered a stranger to the land. It might be urged that inasmuch as the cestui here purported to bind only his heirs and devisees, his assigns are not bound. But it is not necessary to use the word assigns in order that a covenant may run, if the intention is otherwise clear. $^{80}$ Since it is made very clear that the general arrangement was intended to run, it would seem that this covenant also should be held to run. A running covenant for the payment of rent is upheld in New York. ${ }^{81}$ The case seems one more of the rather unfortunate line of New York cases on running covenants.

The court suggests that the plaintiffs are not without remedies, although no particular remedy was suggested. The Appellate Division suggested, however, an action for use and occupation. Apparently this was desired by the defendants, for it would justify them in abandoning the wall and thus avoiding future payments. It is difficult, however, to see how the defendant may be liable for use and occupation if he is not legally obliged to assume the burden of his predecessor in title. In England, where running covenants in fees have been frowned upon by the modern if not by the earlier law, an assignee of the promisee has been able to recover against the original promisor for use and occupation, on the theory that the defendant owes someone. ${ }^{82}$ That case has been criticised, ${ }^{83}$ but it surely does not justify action against another than the promisor. If the covenant does not run the defendant has violated no duty and assumed no obligation by remaining in possession. It is submitted that a sounder method of viewing such covenants is along the line suggested in this article. Possibly the new English Law

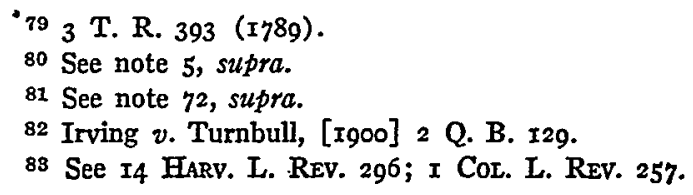


of Property Act may be held to work a reformation in this direction, but it seems more probable that it will be considered as but reaffirming the present rule on this subject. ${ }^{84}$

Charles E. Clark.

Yate LaW School.

84 $\S 96$ of the Law of Property Act, I922, I2 \& I3 Geo. V, c. I6, provides for the running of the benefits or burden of "covenants running with the land," and then states that, for the purposes of the section, a covenant runs "when the benefit or burden of it, whether at law or in equity, passes to the successors in title of the covenantee or the covenantor, as the case may be." Since it is not stated when the benefit or burden will pass, we must probably look to the previous law. Mr. Sims considers the section to have changed the law. See Henry U. Sims, "Notes on Codifying Real Property Law in the United States," 36 HARv. L. REv. 987, 996. But Underhill's view is apparently contrary. See UNDERHIII, LAW of PROPERTY ACT, $7 x$. Other English commentators do not cite this section as one changing the law. I am indebted to Professor Joseph Warren for references on this point, and to an expression of opinion in accord with the view here expressed. 